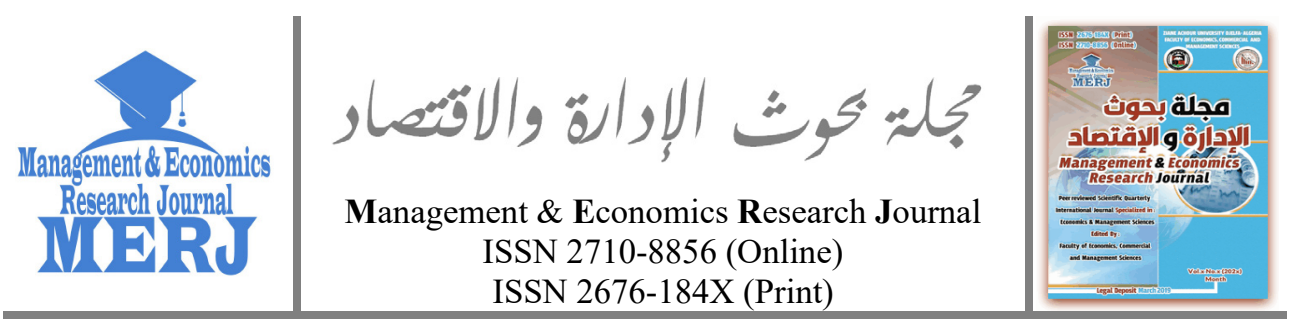

Vol. 4 No. 1 (2022): March, pp. 18-37

doi) https://doi.org/10.48100/merj.2022.167

Check for updates

\title{
Reflecting on the Entrepreneurship Paradox in Sub- Saharan Africa
}

\author{
Charles Mwatsika ${ }^{1(D}$ \\ ${ }^{1}$ Lecturer in Entrepreneurship, Department of Management Studies, Malawi University of \\ Business and Applied Sciences (Malawi) \\ $\bowtie$ cmwatsika@poly.ac.mw
}

\section{How to Cite:}

Mwatsika, C. (2022). Reflecting on the Entrepreneurship Paradox in Sub-Saharan Africa. Management \& Economics Research Journal, 4(1), 18-37. https://doi.org/10.48100/merj.2022.167

\begin{abstract}
:
Entrepreneurship is a strategy for economic growth and is perceived to be higher in developing countries. However, other scholars found that it does not bring economic growth in developing countries. The purpose of the study was to reflect on this paradox in Sub-Saharan Africa from neoclassical economic theory, where entrepreneurship is perceived as carrying out innovations. In Malawi, a cross-sectional survey of enterprises was conducted to assess the values of new products, new production methods, new markets, and new enterprises. A comparison of mean values and two independent sample tests were used to analyse innovations carried out, types of entrepreneurial enterprises, and their prevalence. The study found that carrying out innovations among enterprises in Malawi is low. Very few entrepreneurial enterprises were opportunity-motivated, growth-oriented, and limited liability. Therefore, the paradox depends on the theory which guides the understanding of entrepreneurship. The classical economic perspective
\end{abstract}

- Corresponding author: Malawi University of Business and Applied Sciences (Malawi).

[ $₫$ cmwatsika@poly.ac.mw]

(C2022 the Author(s). This is an open-access article distributed under the terms of (CC BY-NC 4.0) which permits use, distribution and reproduction in any medium, provided the original work is properly cited and is not used for commercial purposes. 
reflects the paradox, while the neoclassical economic perspective does not. This study contributes to knowledge of the types of entrepreneurial enterprises and shows that the paradox depends on the understanding of entrepreneurship. The findings imply that entrepreneurship is ineffective for economic growth in developing countries because of a lack of carrying out innovation. Therefore, the understanding of entrepreneurship in developing countries needs to be adjusted to neoclassical economic theories so that policy focuses on supporting entrepreneurial enterprises for entrepreneurship to be effective for economic growth, ceteris paribus.

Keywords: Business Start-up, Economic Growth, Entrepreneurship Paradox, Innovation.

JEL Codes: L26.

\section{Introduction}

Entrepreneurship attracts scholarly inquiry in developing countries because of its widely accepted importance in economic development and the perceived Entrepreneurship Paradox, hereafter called the paradox. Studies show that entrepreneurship brings about economic growth and creates jobs (Lee \& Xin, 2015; Decker et al., 2014). It is a commonly stated economic development strategy in developing and developed Organisation for Economic Cooperation and Development (OECD) countries (OECD, 2010; Wekwete, 2014). For instance, the Southern Africa Commonwealth Local Government Forum (CLGF) recommended the adoption of Local Economic Development (LED) and entrepreneurship as crucial strategies for attaining economic growth in Southern Africa Development Community (SADC) (Wekwete, 2014).

There are, however, contradictory levels of entrepreneurship and perceptions of its effect on economic growth between developing and developed countries. The Global Entrepreneurship Monitor (GEM, 2018) and the International Labour Organisation (ILO, 2015), using total early-stage entrepreneurial activity (TEA) rate and self-employment rate, respectively, show higher levels of entrepreneurship in developing countries than in developed countries. However, Zaki and Rashid (2016), Stam and van Stel (2009), and van Stel et al. (2005) found a negative relationship between entrepreneurship and economic growth in developing countries, even though entrepreneurial behaviour was high. Lafuente et al. (2018) and Bell (2013) refer to this contradiction as a paradox.

Poor environments for business are considered the main reason for the existence of the paradox (Lafuente et al., 2018). Doing Business report of the World Bank Group (2020) highlights binding constraints which inhibit micro, 
small, and medium enterprises (MSME) sector growth in developing countries. However, the problem is that poverty, unemployment, and poor economic growth persist despite decades of effort to improve the environments for business, entrepreneurship, and MSME sector growth in some Sub-Saharan African countries (Meressa, 2020; Cassim et al., 2014). In Malawi, for example, efforts have been undertaken to establish institutions and improve the environment for businesses to grow the MSME sector since the early 1980s (Masten \& Kandoole, 1997). The TEA rate is high (Dalious et al., 2012), but Gross Domestic Product (GDP) growth is low (Macroeconomic trends, 2021), and poverty and unemployment levels remain high (GOM, 2017). This reflects the paradox's existence and supports empirical studies that found that entrepreneurship does not bring economic growth in developing countries. It further highlights that other factors influence the effect of entrepreneurship because some improvements are noted by the Doing Business report (World Bank Group, 2020) in some SubSaharan African countries, but the paradox persists.

Entrepreneurship has multiple perceptions grounded in both classical and neoclassical economic theories. From the classical economic perspective, entrepreneurship is starting a business or being self-employed (GEM, 2018; ILO, 2015), whereas from the neoclassical economic perspective, it is identifying entrepreneurship opportunities and carrying out innovations that ignite economic change (Shane \& Venkataraman, 2000; Schumpeter, 1934). The former reflects the paradox. However, the neoclassical economic perspective places entrepreneurship at the centre of economic development theory (Schumpeter, 1934). Although there is knowledge about high TEA rates in developing countries (GEM, 2018), which provides the classical economic perspective, there are knowledge gaps on entrepreneurship undertaken from the neoclassical economic perspective, carrying out innovations. Sheriff et al. (2016) assert a lack of knowledge about the types and rates of entrepreneurship undertaken in developing countries. As a result, there are no reflections on the paradox from the neoclassical economic perspective.

Therefore, the study's purpose was to reflect on the paradox from the neoclassical economic perspective while keeping the influence of the environment for business on entrepreneurship constant. It is important to note that entrepreneurship is promoted and supported in Sub-Saharan African countries. However, only some studies assess entrepreneurial activities and innovations to reflect entrepreneurship's productivity and contribution to economic development. Specifically, the study assessed entrepreneurial activities undertaken by different types of enterprises and analysed 
innovations created and their values to determine the prevalence of productive business.

The study is important because entrepreneurship is a strategy for attaining economic growth in most Sub-Saharan African countries. Therefore, reflecting on the paradox is necessary to find ways of making it effective apart from focusing on improving the environment for business. Furthermore, inquiry into the paradox is needed because, firstly, accepting its existence is acknowledging that what is undertaken in developing countries is entrepreneurship expected to ignite economic development. Its failure to do so is thereby a contradiction between theory and empirical evidence. Henrekson and Sanandaji (2014) and Shane (2009) have commented that what is perceived and undertaken as entrepreneurship in developing countries is not all in the modern meaning of the concept. Secondly, accepting the paradox acknowledges that indicators showing higher levels of entrepreneurship in developing countries are appropriate measures of the concept when Ahmad and Hoffman (2007) recognise that none of the indicators captures entrepreneurship conceptually or empirically. Thirdly, accepting the paradox disregards the theory that entrepreneurship brings economic development. Therefore, it should not be pursued as a strategy in developing countries when in practice, countries in Sub-Saharan Africa continue to consider entrepreneurship a method for attaining economic growth (Wekwete, 2014).

The study intended to respond to questions and contribute to knowledge about entrepreneurial activities undertaken in Malawi, types of productive enterprises that require support to contribute more towards economic growth, and the position of the paradox from a neoclassical economic perspective. The paper is presented as follows. First, a review of the meanings and indicators of entrepreneurship is presented, followed by the methodology used to conduct the study. After that, results are presented and discussed before a conclusion is drawn on the implications of findings, study limitations, and areas for future research.

\section{Literature review}

\subsection{Understanding of entrepreneurship and study hypotheses}

Entrepreneurship is a popular concept, but it is inconsistently defined by scholars even though it is grounded in the same classical and neoclassical economic theories. Cantillon (1755) originated the term entrepreneurship referring to activities of individuals alert to market discrepancies and procuring raw materials at specific prices to rework them up and resell them 
at uncertain prices for a profit. These individuals are primarily self-employed and are perceived to undertake risks on capital employed, mainly because of the uncertainty of future resell prices. Say (1816) improved the explanation of entrepreneurship to mean the coordination of factors of production (capital, land, and labour) to produce goods and services, which scholars interpret in two distinct ways. Firstly, coordination of factors of production is interpreted as superintendent of the factors in the production process. Thereby, entrepreneurship is a management function (Leibenstein, 1968). Secondly, the coordination of factors of production is interpreted as uniting factors to create the organisation which produces goods and services. From these two prominent classical economic theorists, Cantillon (1755) and Say (1816), entrepreneurship is commonly defined as founding or creating a new organisation or business (Scarborough, 2013) and management of an enterprise or self-employment, which involves risk (ILO, 2015; Leibenstein, 1968). However, self-employment does not capture the essence of the concept.

Neoclassical economic theorists Schumpeter (1934) and Kirzner (1973) brought a new dimension to the meaning of entrepreneurship. First, Schumpeter (1934) places entrepreneurship at the centre of his economic development theory as the function through which innovations are created. He theorises that innovations create new market disequilibrium and ignite economic development when the economy reorganises towards the new equilibrium. Although Schumpeter (1934) acknowledges that economic development would come from undertaking improvements over time, he asserts that his theory refers to discontinuous innovations as a source of economic development. Second, Kirzner (1973) is accredited for putting forward the meaning of entrepreneurship as the perception and exploitation of opportunities brought by innovative change. While Schumpeter's (1934) entrepreneurship creates new disequilibrium in the markets, Kirzner's (1973) entrepreneurship moves the markets towards a new equilibrium, and both forms of entrepreneurship are responsible for economic development (Schmitz, 1989). Therefore, based on neoclassical economic theory, entrepreneurship is commonly defined as innovations that ignite economic change or perception and exploitation of opportunities brought by the change (Shane \& Venkataraman, 2000). This is the modern meaning of entrepreneurship (Henrekson \& Sanandaji, 2014) and the preferred perception because it captures entrepreneurship as a source of economic growth. It is expected that understanding entrepreneurship through either classical or neoclassical economic perspectives would lead to undertaking entrepreneurial activities with varying effects on economic growth due to 
differences in the focus on innovation.

However, it is noted in the literature that starting a new enterprise or business is a common explicit and implicit definition of entrepreneurship. Because enterprises start small and grow over time, the classification of enterprises by size makes the prevalence of MSMEs a common indicator of entrepreneurship in an economy. MSMEs are, therefore, frequently viewed synonymously with entrepreneurship (Acs \& Virgill, 2009), and the MSME sector is considered essential for economic growth. Nevertheless, it is recognised that not all MSMEs can bring economic growth (Shane, 2009). That means not all MSMEs represent entrepreneurship from the neoclassical economic perspective. Therefore, scholars present further classifications of enterprises to identify MSMEs that can bring economic growth.

One of these classifications is based on motivation for establishing an enterprise. While various external factors affect overall entrepreneurial behaviour in an economy (Rusu \& Roman, 2017), individuals are driven to start a new enterprise by either a perception of entrepreneurship opportunities (pull factors) or necessity (push factors), such as unemployment or lack of alternative means to earn a living (Mwatsika, 2015). Therefore, scholars assert that opportunity-motivated enterprises (OMEs) are more productive than necessity-motivated enterprises (NMEs) (Bell, 2013). Although levels of NMEs can be high in both developed and developing countries, GEM (2018) shows that OMEs are most prevalent in developed countries. Therefore, the fewer OMEs in developing countries could be one possible cause of the paradox. However, only some studies have measured differences in entrepreneurship between NMEs and OMEs in Sub-Saharan Africa to reflect on potential differences in their contribution to economic productivity. The study, therefore, assessed differences in entrepreneurship undertaken between NMEs and OMEs by testing the following first hypothesis.

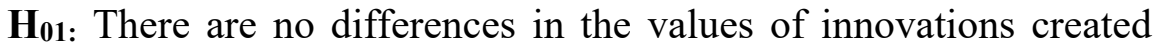
between necessity-motivated and opportunity-motivated enterprises.

In the second classification, scholars differentiate between lifestyle and growth enterprises in the entrepreneurship literature. Burns (2016) defines a lifestyle enterprise as (one which allows the founder to pursue a particular lifestyle while earning a good living). This enterprise has a limited growth orientation, whereas a growth enterprise is started with an ambition for high growth. OECD (2010) defines a high-growth enterprise (HGE) as one with average annualised growth of over 20 per cent over three years and ten or more employees at the beginning of the observation period. HGEs are 
associated with innovation. Brown and Mawson (2015) assert that they grow discontinuously, reflecting entrepreneurship from a neoclassical economic perspective. Although HGEs represent a small proportion of all MSMEs (Anyadike-Danes et al., 2013), scholars associate them with economic growth and job creation (Decker et al., 2014; Stam \& van Stel, 2009; Shane, 2009). As such, they are of particular policy interest in developed OECD countries (Bosma \& Stam, 2012). However, there are differences in the prevalence of HGEs between developed and developing countries. The assertion by Olafsen and Cook (2016) that there are fewer HGEs and a higher prevalence of lifestyle enterprises in developing countries is thereby propagated as one of the reasons for the paradox. Goedhuys and Sleuwaegen (2010) investigated the employment creation of HGEs in Sub-Saharan Africa. Still, there are few studies on the differences in entrepreneurship undertaken between lifestyle and HGEs to reflect on potential differences in their contribution towards economic productivity. The study, therefore, assessed the differences in entrepreneurship undertaken between lifestyle and growth enterprises by testing the following second hypothesis.

H02: There are no differences in the values of innovations created between lifestyle and growth-oriented enterprises.

The third classification of enterprises of interest was based on the structure of ownership; sole proprietorship and limited liability enterprises. In developing countries, most start-ups are sole proprietorship enterprises that operate in the informal sector. In Malawi, $89 \%$ of MSMEs are informal (Finscope, 2019). This contrasts with developed countries, where most startups are formal firms (Munemo, 2012). The key issues studied between the categories relate to how they contribute to economic growth, job creation, taxes, and factors influencing their creation. Incorporated enterprises are perceived to be more productive for economic growth because of formal structures, market-entry order, access to resources for innovation, formal planning, and managers' encouragement to take risks, among other factors (Pearce et al., 1997; Burgelman, 1985). Therefore, the higher prevalence of sole proprietorship and fewer incorporated enterprises is presumed to be one of the contributing factors to the paradox in developing countries. However, few studies have compared entrepreneurship undertaken by enterprises in these categories to assess their influence on economic growth. The study, therefore, assessed the differences in entrepreneurship undertaken between a sole proprietorship and incorporated enterprises by testing the following third hypothesis. 
$\mathbf{H}_{03}$ : There are no differences in the values of innovations created between a sole proprietorship and limited liability enterprises.

This review has provided an understanding of entrepreneurship from both classical and neoclassical economic perspectives. The study has identified specific categories of MSMEs, guided measuring of their innovations and values, and tested study hypotheses. It will help to reflect on the paradox from the neoclassical economic perspective.

\subsection{Measurement of entrepreneurship and the paradox}

The indicators used to measure entrepreneurship depend on the definition of entrepreneurship and data availability (Low, 2009). Entrepreneurial behaviour, output, and outcome indicators measure entrepreneurship grounded in classical economic theory. However, measuring entrepreneurship as a perception of opportunities and carrying out innovations from the neoclassical economic perspective has been challenging. Therefore, proxy indicators such as Research and Development (R\&D) expenditure, venture capital availability, and registered patents are often used (Kukoc \& Regan, n.d.). There are attempts to develop appropriate indicators of Schumpeterian entrepreneurship, such as Henrekson and Sanandaji's (2014) proposed use of the number of a country's billionaires on the Forbes List.

TEA rate is a popular indicator of entrepreneurial behaviour used by GEM. A proportion of the population aged between 18 and 64 are actively involved in starting a business, are nascent entrepreneurs, have started less than 42 months old, and are new business owners/managers (Bosma et al., 2012). GEM is a popular database for undertaking empirical analyses because it covers many countries (Bosma et al., 2012) and was used in studies by Stam and van Stel (2009) and van Stel et al. (2005) as TEA is one of the indicators which reflect the paradox in developing countries.

Entrepreneurship output indicators concentrate on new organisations. However, Schumpeter (1934) provides five categories of innovations (new goods or services, new methods of production, new sources of supply of raw materials, new markets, and new ways of organisation industry) as outputs of entrepreneurial behaviour. Some entrepreneurship output and outcome indicators include; business start-up rates, business death rates, business churn, business ownership rates, self-employment rates, and the prevalence of MSMEs (Ahmad \& Hoffman, 2007; Henrekson \& Sanandaji, 2014). Zaki and Rashid (2016) used new establishments as a proxy for entrepreneurship when they found a negative relationship between entrepreneurship and 
economic growth in developing countries. The availability of data from business registration offices and labour office surveys allows measurement and comparison of entrepreneurship across countries using the output and outcome indicators.

It is common for behavioural, output, and outcome indicators to show that entrepreneurship is higher in developing countries than in developed countries. For instance, GEM (2018) and ILO (2015) show that entrepreneurial behaviour and self-employment are higher in developing than developed countries. However, indicators that attempt to capture entrepreneurship as a perception of opportunity and carrying out innovations show that entrepreneurship is higher in developed countries than in developing countries (Olafsen \& Cook, 2016). Munemo (2012) asserts that firm start-up rates are higher in developed than in developing countries. Therefore, there are contradictions in entrepreneurship levels between developing and developed countries. Nonetheless, necessity-motivated entrepreneurial behaviour, business start-ups, and self-employment, highly prevalent in developing countries (GEM, 2018; ILO, 2015), reflect the paradox because they do not help achieve economic development (Shane, 2009).

This review provides two key observations. The first one is that the paradox is reflected through entrepreneurship from the classical economic perspective, which is not at the centre of economic development theory. Scholars; Henrekson and Sanandaji (2014) and Shane (2009) have argued that most self-employment and MSMEs in developing countries do not carry out innovations that can ignite economic development. The second observation is that those measurement indicators applied do not capture entrepreneurship conceptually or empirically (Ahmad \& Hoffman, 2007). There are limitations with TEA, business start-up rates, the prevalence of MSMEs, and selfemployment as measures of entrepreneurship (Desai, 2017; Bergman \& Stephan, 2013; Shane, 2009; Ahmad \& Hoffman, 2007; Kukoc \& Regan, n.d.).

Nonetheless, the paradox is premised on the assumption that entrepreneurship in developing countries can ignite economic development. Therefore, arguments for the paradox's existence focus on poor business environments in developing countries (Lafuente et al., 2018). However, despite decades of efforts to improve the environment for business, the expected economic development is not realised, as observed by Meressa (2020) and Cassim et al. (2014) for Ethiopia and South Africa, respectively. This reflects the contexts of other developing countries such as Malawi.

The study thereby attempted to reflect on the paradox from the 
neoclassical economic perspective. Schumpeter (1934) asserts that entrepreneurship is recognised when innovations are carried out. Therefore, innovations are an appropriate measure of the concept, including new products, new production methods, new markets, and new organisations in any industry. Kotler and Armstrong (2012) define a product as anything that can be offered to a market for attention, acquisition, use, or consumption that might satisfy a want or need. A new product is an improved, imitated, or new brand developed through R \& D efforts (Kotler \& Armstrong, 2012); its value is the exchange value realised when the product is traded (Bowman \& Ambrosini, 2003). Schumpeter (1934) defines a new method of production as (one that is not yet tested by experience in the branch of manufacture concerned, which by no means be founded upon a discovery scientifically new and can also exist in a new way of handling a commodity commercially). A new method of production would mean an improved, replicated, or newly developed through $\mathrm{R} \& \mathrm{D}$, and its investment value is considered its value in the study. A new market is one into which a particular branch of manufacture of a country in question has not previously entered, whether such a market exists (Schumpeter, 1934). The value of a market is the aggregate exchange value realised from products sold. A new organisation is less than three and a half R\&D years old (Bosma et al., 2012). The organisation's value is the measurable and transferable present worth (Fisher \& Lentz, 1990), which is its assets less its current liabilities (Miciula et al., 2020). The aggregate value of innovations carried out represents entrepreneurship value, the contribution towards economic productivity from entrepreneurship undertaken in the economy. Entrepreneurship was therefore measured from the neoclassical economic perspective to reflect on the paradox.

\section{Methodology}

A cross-sectional survey of enterprises was undertaken in three cities and three rural growth centres. Malawi has approximately 1.6 million MSMEs (Finscope, 2019), and 384 enterprises were adopted as an appropriate study sample (Saunders et al., 2009, p.219). Non-probability sampling approaches were used because Malawi has no database of all MSMEs. Cities have the largest concentration of enterprises in the country; therefore, they constituted 75 per cent of the sample based on the rule of thumb principle. The first enterprise was randomly selected among the first three in each location. After that, every third enterprise was sampled without replacement to ensure an unbiased selection of participants. Enterprise owners and managers were the key respondents in the study.

A questionnaire was used to collect data. In the first section, 
respondents' details (sex, age, education, and position) and enterprise details (type of ownership, motivation for establishment, the year the enterprise started, objective of establishment, current number of employees, and number of employees a year earlier) were collected. The details were used to classify enterprises by type of ownership (sole proprietorship or limited liability enterprise), motivation of entrepreneurial behaviour (necessity or opportunity), age of enterprise (new or old), the objective of the enterprise (profit-making or non-profit making), size of the enterprise (micro, small, medium, or large) and growth orientation (lifestyle or growth enterprise). In the next section, innovations were carried out, and their values were recorded. Respondents were requested to provide; (1) asset book values of their enterprises and their current liabilities position, (2) new products the enterprises created and introduced into the market over the past year together with market exchange values realised. (3) New methods of production created over the past year and their investment values, and (4) new markets entered by the enterprises over the past year together with product exchange values realised. These details were collected to calculate the present worth of new enterprises, the values of new products and production methods created, and the value of new markets. Data collected covered the financial year starting April 2019 to March 2020. The content validity of the questionnaire was ensured, and it was piloted in the City of Mzuzu before the commencement of the survey.

Descriptive statistics (frequencies), comparison of mean values, and non-parametric tests (2 independent sample test, Mann-Whitney U test) were used to learn about the types of enterprises in the study, those that carried out innovations, the values of innovations undertaken, and differences in values of innovations between types of enterprises to reflect on the paradox. Nonparametric tests were used because residuals of the outcome value did not meet the normality assumption during exploratory data analysis.

\section{Results and discussion}

Three hundred thirty-seven enterprises participated in the study representing 88 per cent of the targeted sample size. Table 1 presents descriptive statistics of the study sample. 
Table 1. Categories of enterprises studied

\begin{tabular}{|c|c|c|c|c|}
\hline No & Basis of classification & Category & Frequency & Percentage \\
\hline \multirow{2}{*}{1} & \multirow{2}{*}{ Type of ownership } & Sole proprietorship & 318 & 94.4 \\
\hline & & Limited liability enterprise & 19 & 5.6 \\
\hline \multirow{2}{*}{2} & \multirow{2}{*}{ Age of enterprise } & Old (above 42 months) & 243 & 72.1 \\
\hline & & New (up to 42 months) & 94 & 27.9 \\
\hline \multirow{2}{*}{3} & \multirow{2}{*}{ Motivation for establishment } & Necessity-motivated & 273 & 81.0 \\
\hline & & Opportunity-motivated & 64 & 19.0 \\
\hline \multirow{2}{*}{4} & \multirow{2}{*}{ Objective of enterprise } & Profit-making & 325 & 96.4 \\
\hline & & Non-profit making & 12 & 3.6 \\
\hline \multirow{5}{*}{5} & \multirow{5}{*}{ Size of enterprise } & Microenterprise & 157 & 46.6 \\
\hline & & Self-employed/Independent & 98 & 29.1 \\
\hline & & Small enterprise & 71 & 21.1 \\
\hline & & Medium enterprise & 9 & 2.7 \\
\hline & & Large enterprise & 2 & 0.6 \\
\hline \multirow{2}{*}{6} & \multirow{2}{*}{ Growth orientation } & Lifestyle enterprise & 330 & 97.9 \\
\hline & & Growth enterprise & 7 & 2.1 \\
\hline \multirow{2}{*}{7} & \multirow{2}{*}{ Formality of enterprise } & Formal (registered) & 181 & 53.7 \\
\hline & & Informal (unregistered) & 156 & 46.3 \\
\hline
\end{tabular}

Sample $=337$ Enterprises.

Size of enterprise: self-employed/Independent $=$ no employees, microenterprise $=1-4$ employees, small enterprise $=5-20$ employees, medium enterprise $=21-100$ employees, and large enterprise $=$ $100+$ employees (GOM, 2012).

It is necessary to note that enterprises classified as sole proprietorships, necessity-motivated, self-employed, micro, small, and lifestyle are the most prevalent. Table 2 presents innovations carried out in enterprises studied and their mean values.

Table 2. Innovations carried out and their mean values

\begin{tabular}{|c|c|c|c|c|c|c|c|}
\hline \multicolumn{8}{|c|}{$\begin{array}{l}\text { Innovations and their mean values (US\$) } \\
\text { Sample }=337(100 \%)\end{array}$} \\
\hline \multicolumn{2}{|c|}{ New products } & \multicolumn{2}{|c|}{$\begin{array}{l}\text { New methods of } \\
\text { production }\end{array}$} & \multicolumn{2}{|c|}{ New markets } & \multicolumn{2}{|c|}{ New enterprises } \\
\hline $\begin{array}{l}\text { Frequency } \\
\text { (per cent) }\end{array}$ & $\begin{array}{l}\text { Mean value } \\
\text { US\$ }\end{array}$ & $\begin{array}{l}\text { Frequency } \\
\text { (Percent) }\end{array}$ & $\begin{array}{l}\text { Mean } \\
\text { value US\$ }\end{array}$ & $\begin{array}{l}\text { Frequency } \\
\text { (Percent) }\end{array}$ & $\begin{array}{l}\text { Mean value } \\
\text { US\$ }\end{array}$ & $\begin{array}{l}\text { Frequency } \\
\text { (per cent) }\end{array}$ & $\begin{array}{l}\text { Mean value } \\
\text { US\$ }\end{array}$ \\
\hline $84(25 \%)$ & 12003 & $7(2 \%)$ & 1719 & $4(1.2)$ & 1420 & $94(28 \%)$ & 8874 \\
\hline
\end{tabular}

*Exchange rate: US\$ 1 = Malawian Kwacha (MK) 745.

The results showed that very few enterprises carried out innovations, and their values were very low. Particularly, there was a lack of entrepreneurial activity in creating new production methods and seeking new markets among the enterprises studied. Although 25 per cent of enterprises carried out new products, they referred to product improvements and imitations, most of which were new at the enterprise level but few at the 
country level. The internet was a commonly cited source of new product ideas (imitations), and none of the enterprises studied had R\&D programmes for new product development. The results demonstrate that entrepreneurship is low in Malawi when perceived from the neoclassical economic perspective as carrying out innovations.

In the following analyses, the values of innovations created were compared between classes of enterprises. Two independent sample tests (Mann-Whitney U test) were undertaken to test the study's hypotheses. The first hypothesis was that there are no differences in the values of innovations created between necessity-motivated and opportunity-motivated enterprises. Mann-Whitney $U$ test results, Table 3, showed statistically significant differences between opportunity-motivated and necessity-motivated enterprises in the values of new enterprises (ENTV) $(p=0.002)$, new production methods $(\mathrm{NMPV})(\mathrm{p}=0.001)$ and new markets $(\mathrm{NMKV})(\mathrm{p}=$ $0.001)$. However, there were no statistically significant differences in the values of new products (NPSV) $(p=0.592)$. The results rejected the first hypothesis. Opportunity-motivated enterprises created more value for innovations than necessity-motivated enterprises.

Table 3. Differences in values of innovations between necessity-motivated and opportunitymotivated enterprises

\begin{tabular}{lllll}
\hline & & Necessity motivated & Opportunity motivated & P-value \\
\hline $\begin{array}{l}\text { Number } \\
\begin{array}{l}\text { Median (IQ } \\
\text { range) }\end{array}\end{array}$ & ENTV & 273 & 64 & \\
& NPSV & $0(0)$ & $4302500(119137500) *$ & 0.002 \\
& NPMV & $0(0)$ & $0(1098750)$ & 0.592 \\
& NMKV & $0(0)$ & $0(0) *$ & 0.001 \\
& & $0(0) *$ & 0.001 \\
\hline
\end{tabular}

The second hypothesis was that there are no differences in the values of innovations created between lifestyle and growth-oriented enterprises. Mann-Whitney $U$ test results, Table 4, showed statistically significant differences between growth-oriented and lifestyle enterprises in the values of new enterprises $(E N T V)(p=0.047)$, new products $(N P S V)(p=0.001)$, and new markets $(\mathrm{NMKV})(\mathrm{p}=0.021)$. Nevertheless, there were no statistically significant differences in values of new production methods (NMPV) ( $p=$ 0.163). The second hypothesis was thereby rejected. Growth-oriented enterprises created more value for innovations than lifestyle enterprises. 
Table 4. Differences in values of innovations between lifestyle and growth-oriented enterprises

\begin{tabular}{lllll}
\hline & & Lifestyle & Growth-oriented & P-value \\
\hline $\begin{array}{l}\text { Number } \\
\begin{array}{l}\text { Median }(I Q \\
\text { range) }\end{array}\end{array}$ & ENTV & $2000000(8500000)$ & 7 & \\
& NPSV & $0(0)$ & $3410000(8220000) *$ & 0.001 \\
& NPMV & $0(0)$ & $0(0)$ & 0.163 \\
& NMKV & $0(0)$ & $0(0) *$ & 0.021 \\
\hline
\end{tabular}

The third hypothesis was that there are no differences in the values of innovations created between sole proprietorships and limited liability enterprises. Mann-Whitney U test results, Table 5, showed statistically significant differences between limited liability enterprises and sole proprietorships in the values of new enterprises $(E N T V)(p=0.006)$, new production methods $(\mathrm{NPMV})(\mathrm{p}=0.001)$, and new markets $(\mathrm{NMKV})(\mathrm{p}=$ $0.007)$. There were no statistically significant differences in the values of new products $(\mathrm{NPSV})(\mathrm{p}=0.694)$. The third hypothesis was rejected. Limited liability enterprises created more value for innovations than sole proprietorship enterprises.

Table 5. Differences in values of innovations between Sole proprietorship and limited liability enterprises

\begin{tabular}{lllll}
\hline & & Sole & Limited liability & P-value \\
\hline $\begin{array}{l}\text { Number } \\
\begin{array}{l}\text { Median (IQ } \\
\text { range) }\end{array}\end{array}$ & ENTV & $2000000(6500000)$ & 19 & \\
& NPSV & $0(21500)$ & $0(1300000)$ & 0.006 \\
& NPMV & $0(0)$ & $0(3400000) *$ & 0.694 \\
& NMKV & $0(0)$ & $0(0)^{*}$ & 0.001 \\
& & & 0.007 \\
\hline
\end{tabular}

Overall, the results rejected the study's hypotheses. Opportunitymotivated, growth-oriented, and limited liability enterprises created more value for innovations than necessity-motivated, lifestyle, and sole proprietorship enterprises, thereby underscoring the former as types of entrepreneurial MSMEs.

The following is the learning generated from the findings of the study. There are contrasting levels of entrepreneurship from the classical and neoclassical economic perspectives. Malawi has a higher TEA rate (Dalious et al., 2012), which means a higher proportion of the adult population is engaged in entrepreneurial activities. According to the study's findings, 
necessity-motivated, lifestyle, and sole proprietorships are the most prevalent types of enterprises. However, when entrepreneurship is perceived through neoclassical economic theory as carrying out innovations, it is extremely low in Malawi. The majority of enterprises do not undertake innovations. Therefore, the country's entrepreneurship level depends on understanding the concept. It is high from a classical economic perspective and low from a neoclassical economic perspective. This demonstrates the need for a proper understanding of entrepreneurship development concepts.

The findings prove that opportunity-motivated, growth-oriented, and incorporated enterprises are more entrepreneurial than necessity-motivated, lifestyle, and sole proprietors. The study supports scholars (Bell, 2013; Stam \& van Stel, 2009; Pearce et al., 1997) on productivity and the importance of opportunity-motivated, growth-oriented, and incorporated enterprises in economic growth. The findings further agree with Olafsen and Cook (2016) and GEM (2018) on the higher prevalence of lifestyle and necessitymotivated enterprises and the low presence of opportunity-motivated and growth-oriented enterprises in developing countries. The results support Shane's (2009) assertion that entrepreneurship undertaken in developing countries is less productive toward economic development because only some MSMEs undertake innovations.

It is further explained from the findings that perceptions of the paradox depend on the understanding of entrepreneurship. Entrepreneurship in the classical economic perspective, reflected through TEA (Dalious et al., 2012), is high in Malawi, but most MSMEs do not carry out innovations. Therefore, they do not contribute significantly toward economic growth and reflect the paradox. However, entrepreneurship from a neoclassical economic perspective reflected through carrying out innovations is low, as per study findings. Only some MSMEs carry out innovations to contribute significantly toward economic growth. From this perspective, there is no paradox. Therefore, policy in Malawi would need to align with neoclassical economic perspectives of entrepreneurship. Schumpeter (1934) placed entrepreneurship, as carrying out innovations, at the centre of economic development theory, and various scholars agree that entrepreneurship brings economic growth (Lee \& Xin, 2015; Decker et al., 2014). Therefore, as MSME policy in Malawi focuses on institutional reforms and improving the environment for businesses to enhance MSME sector growth, the focus on carrying out innovations is fundamental for entrepreneurship to influence economic growth positively. That means finding ways to increase opportunity-motivated, growth-oriented, and incorporated enterprises undertaking innovations. 
Meressa (2020) and Cassim et al. (2014) observed that efforts are undertaken to improve the environments for business in Ethiopia and South Africa, respectively. However, expected results in economic development are not achieved. Suppose the contexts of these countries and others in SubSaharan Africa are similar to Malawi, as reflected in the study findings. It is argued that entrepreneurship is ineffective because most enterprises do not produce innovations that increase productivity, competitiveness, and economic growth. Since entrepreneurship is recommended for adoption as a strategy for economic development in SADC countries (Wekwete, 2014), it would be necessary to adjust perceptions of the concept in the region to neoclassical economic theories. That will guide MSME policies and entrepreneurship development initiatives to focus on creating the requisite environments for business that would promote innovation, competition, and growth of productive enterprises that would eventually induce economic growth. Without the necessary adjustments in knowledge about entrepreneurship, the status quo reflecting the paradox shall prevail.

The study's contribution is that perceptions of the paradox (Lafuente et al., 2018; Bell, 2013) in developing countries depend on what is perceived and undertaken as entrepreneurship ceteris paribus. Nonetheless, neoclassical economic theory (Schumpeter, 1934; Kirzner, 1973), which informs the modern understanding of entrepreneurship (Henrekson \& Sanandaji, 2014), is appropriate when contemplating entrepreneurship within economic development theory. A paradigm shift is, therefore, necessary to perceive entrepreneurship as perception and carrying out innovations if entrepreneurship is to become an effective strategy for economic development in developing countries.

\section{Conclusion}

The purpose of the study was to reflect on the entrepreneurship paradox in Sub-Saharan Africa from a neoclassical economic perspective. Measurement of entrepreneurship as carrying out innovations among enterprises in Malawi revealed that entrepreneurship is extremely low in the country. Opportunity-motivated, growth-oriented, and limited liability enterprises are the entrepreneurial types of enterprises, but there are very few. Most enterprises are necessity-motivated, lifestyle and sole proprietorships that do not undertake innovations. The study found that the perception of the paradox in developing countries (Lafuente et al., 2018; Bell, 2013) is contentious. It depends on the theories which guide the understanding of entrepreneurship. Entrepreneurship from a classical economic perspective (as starting a new business or enterprise) reflects the paradox. In contrast, 
entrepreneurship from a neoclassical economic perspective, as a perception of opportunities and carrying out innovations, does not reflect the paradox.

The study contributes to the knowledge that opportunity-motivated, growth-oriented, and limited liability enterprises are the entrepreneurial types of MSMEs. That perception of the paradox depends on scholars' understanding of entrepreneurship. However, since the neoclassical economic perspective places entrepreneurship at the centre of economic development theory, it is recommended that the understanding of entrepreneurship in Malawi be adjusted to neoclassical economic theories. Secondly, refocus efforts on reforming institutions and improving environments for businesses to support the growth of the entrepreneurial types of enterprises. That will increase the number of entrepreneurial enterprises and improve firm and industry competitiveness and overall economic productivity.

If the context of Malawi revealed by the study findings positively reflects other countries in Sub-Saharan Africa, then it is concluded that entrepreneurship does not bring economic growth in developing countries (Zaki \& Rashid, 2016; Stam \& van Stel, 2009) because the majority of enterprises do not carry out innovations. The findings agreed with Shane (2009) that not all MSMEs are entrepreneurial to contribute significantly toward economic growth. Therefore, adjusting the understanding of entrepreneurship to neoclassical economic theories is recommended in the region to guide policy if entrepreneurship is to become an effective strategy for economic growth.

However, the fact that the study was undertaken in only one country limits the position reached. Therefore, further studies are encouraged to replicate this research in Sub-Saharan African countries to measure innovations created in enterprises and determine the types of entrepreneurial MSMEs. This will inform policy on support required by entrepreneurial MSMEs and invigorate efforts in institutional reforms and improvement of business environments to enhance entrepreneurship's effectiveness on economic growth in the region.

\section{Declaration of conflicting interests}

The author(s) declared no potential conflicts of interest with respect to the research, authorship, and/or publication of this article. 


\section{References}

Acs, Z., \& Virgill, N. (2009). Entrepreneurship in developing countries. Jena Economic Research Papers, No. 2009, 023, Friedrich Schiller University, Jena and Max Planck Institute of Economics. Jena.

Ahmad, N., \& Hoffman, A. (2007). A Framework for addressing and measuring entrepreneurship. OECD, Paris.

Anyadike-Danes, M., Bonner, K., \& Hart, M. (2013). Exploring the incidence and spatial distribution of high growth firms in the UK and their contribution to job creation, NESTA Working Paper 13/05 London.

Bell, L. (2013). Entrepreneurship and local economic growth in emerging markets. Utrecht Centre for Entrepreneurship, The Netherlands.

Bergmann, H., \& Stephan, U. (2013). Moving on from nascent entrepreneurship: Measuring cross-national differences in the transition to new business ownership. Small Business Economics, 41(4), 945-959. https://doi.org/10.1007/s11187-012-9458-4

Bosma, N., Coduras, A., Litovsky, Y., \& Seaman, J. (2012). GEM Manual: A report on the design, data and quality control of the Global Entrepreneurship Monitor. GEM Consortium.

Bosma, N., \& Stam, E. (2012). Local policies for high-growth enterprises. Report prepared for the OECD/DBA International Workshop on high-growth firms: Local policies and local determinants. Copenhagen, March 12, 2012.

Bowman, C., \& Ambrosini, V. (2003). What does value mean and how is it created, maintained and destroyed? Academy of Management Annual Meeting, Seattle, Washington, 1-6 August.

Brown, R., \& Mawson, S. (2015). The geography of job creation in high growth firms: The implication of growing abroad. Environment and Planning C: Government and Policy, 34(2), 207-227. https://doi.org/10.1177/0263774x15614152

Burgelman, R.A. (1985). Managing the new venture division: Research findings and implications for strategic management. Strategic Management Journal, 6(1), 39-54. https://doi.org/10.1002/smj.4250060104

Burns, P. (2016). Entrepreneurship and small business start-up, growth and maturity $\left(4^{\text {th }}\right.$

Ed). Palgrave.

Cantillon, R. (1755). Essay on the Nature of Trade in General. London: Henry Higgs (edition and translation 1959).

Cassim, S., Soni, P., \& Karodia, A. (2014). Entrepreneurship policy in South Africa. Arabian Journal of Business and Management Review, 3(9), 29-43.

Dalious, M., Mandere, G., Jamali-Phiri, M., \& Kaneka, B. (2012). Global entrepreneurship monitor Malawi report 2012. Global Entrepreneurship Research Association, UK.

Decker, R., Haltiwanger, J., Jarmin, R., \& Miranda, J. (2014). The role of entrepreneurship in US job creation and economic dynamism. The Journal of Economic Perspectives, 28(3), 3-24. https://doi.org/10.1257/jep.28.3.3

Desai, S. (2017). Measuring entrepreneurship: Type, motivation and growth. Indiana University, USA. https://doi.org/10.15185/izawol.327

Finscope (2019). Micro, small and medium enterprises survey, Malawi. Finmark Trust.

Fisher, J. D., \& Lentz, G. H. (1990). Business enterprise value in shopping malls: An empirical test. The Journal of Real Estate Research, 5(1), 167-175. https://doi.org/10.1080/10835547.1990.12090611

Global Entrepreneurship Monitor (2018). Global Entrepreneurship Monitor Global Report 
2017-2018, Wellesley, MA, Babson College.

Goedhuys, M., \& Sleuwaegen, L. (2010). High growth entrepreneurial firms in Africa: A quantile regression approach. Small Business Economics, 34, 31-51. https://doi.org/10.1007/s11187-009-9193-7

Government of Malawi (GOM). (2017). Economic development document for Malawi. Ministry of Finance Economic Planning and Development, Lilongwe, Malawi.

Government of Malawi (GOM). (2012). Micro small and medium enterprises (MSME) policy strategy for the Republic of Malawi. Prepared by Chris Darroll, SBP, Johannesburg, South Africa.

Henrekson, M., \& Sanandaji, T. (2014). Small business activity does not measure entrepreneurship. National Academy of Sciences, 111(5), 1760-1765. https://doi.org/10.1073/pnas.1307204111

International Labour Organisation (ILO) (2015). Small and medium-sized enterprises and decent and productive employment creation. International Labour Conference, $104^{\text {th }}$ Session, International Labour Office, Geneva.

Kirzner, I. (1973). Competition and Entrepreneurship, Chicago: University Press, Chicago. Kotler, P., \& Armstrong, G. (2012). Principles of Marketing, $14^{\text {th }}$ ed. Pearson Prentice Hall.

Kukoc, K., \& Regan, D. (n.d.). Measuring entrepreneurship. Macroeconomic Policy Division, Australian Treasury.

Lafuente, E., Acs, Z., \& Szerb, L. (2018). The entrepreneurship paradox: More entrepreneurs are not always good for the economy- The role of the entrepreneurial ecosystem on economic performance in Africa. SSRN Working Paper Series. https://doi.org/10.1007/bf02930008

Lee, K., \& Xin, S. (2015). Firm size and economic growth in China. Journal of International and Area Studies, 22(1), 93-112.

Leibenstein, H. (1968). Entrepreneurship and development. American Economic Review, $58(2)$,

Low, S. A. (2009). Defining and measuring entrepreneurship for regional research: A new approach. Dissertation, Urbana, Illinois.

Macroeconomic trends (2021). Malawi Gross Domestic Product 1960-2021. https://www.macrotrends.net/countries/MWI/Malawi/gdp-gross-domesticproduct $>$ MalawiGDP1960-2021

Masten, J., \& Kandoole, B. (1997). The capacity of small and medium enterprises support in Malawi to support small business expansion. Lilongwe, Malawi: Malawi Institute of Management.

Meressa, H. A. (2020). Growth of micro and small scale enterprises and its driving factors: Empirical evidence from entrepreneurs in emerging region of Ethiopia. Journal of Innovation and Entrepreneurship, 9(11), 1-22. https://doi.org/10.1186/s13731-020$00121-9$

Miciula, I., Kadlubek, M., \& Stepien, P. (2020). Modern methods of Business Valuation Case study and new concepts. Sustainability, 12, 1-22. https://doi.org/10.3390/su12072699

Munemo, J. (2012). Entrepreneurship in developing countries: Is Africa different? Journal of Developmental Entrepreneurship, 17(1), 1-12. https://doi.org/10.1142/s1084946712500045

Mwatsika, C. (2015). Entrepreneurship development and entrepreneurial orientation in rural areas in Malawi. African Journal of Business Management, 9(9), 425-436.

Organisation for Economic Cooperation and Development (OECD). (2010). High growth 
enterprises: What governments can do to make a difference? OECD Studies on SMEs and entrepreneurship, Organisation for Economic Cooperation and Development, Paris.

Olafsen, E., \& Cook, P.A. (2016). Growth entrepreneurship in developing countries: A preliminary literature review. Washington, DC: The World Bank Group.

Pearce, J. A., Kramer, T. R., \& Robbins. D. K. (1997). Effects of managers' entrepreneurial behaviour on subordinates. Journal of Business Venturing, 12, 147-160. https://doi.org/10.1016/s0883-9026(96)00066-3

Rusu, V.D., \& Roman, A. (2017). Entrepreneurial activity in the EU: An empirical evaluation of its determinants. Sustainability, 9, 1-16. https://doi.org/10.3390/su9101679

Saunders, M., Lewis, P., \& Thornhill, A. (2009). Research methods for business students, $5^{\text {th }}$ edition. Prentice-Hall.

Say, J.A. (1816). A Treatise on Political Economy. London: Sherwood, Neeley and Jones.

Scarborough, N. (2013). Essentials of entrepreneurship and small business management, Sixth Ed. Pearson.

Schmitz, J. A. (1989). Imitation, entrepreneurship and long-run growth. Journal of Political Economy, 97(3), 721-739. https://doi.org/10.1086/261624

Schumpeter, J.A. (1934). The theory of economic development. Cambridge, MA: Harvard Economic Studies.

Shane, S. (2009). Why encouraging more people to become entrepreneurs is bad public policy. Small Business Economics, 33(2), 141-149. https://doi.org/10.1007/s11187009-9215-5

Shane, S., \& Venkataraman, S. (2000). The promise of entrepreneurship as a field of research. Academy of management review, 25(1), 217-226. https://doi.org/10.5465/amr.2000.2791611

Sheriff, M., Muffatto, M., \& Cooper, S. (2016). Measuring entrepreneurship environments in Africa: challenges in using international reports. International Journal of Entrepreneurship and Innovation Management, 20(1/2), 20-44. https://doi.org/10.1504/ijeim.2016.075297

Stam, E., \& van Stel, A. (2009). Types of entrepreneurship and economic growth. Research paper 2009/47, WIDER Research Paper, Helsinki.

Van Stel, A., Carree, M., \& Thurik, R. (2005). The effect of entrepreneurial activity on national economic growth. Small Business Economics, 24(3), 311-321. https://doi.org/10.1007/s11187-005-1996-6

Wekwete, K. (2014). Local government and local economic development in Southern Africa. Commonwealth Local Government Forum.

World Bank Group (2020). Doing business 2020: Comparing business regulation in 190 economies. Washington, DC: World Bank Group. https://doi.org/10.1596/978-14648-1440-2

Zaki, I.M., \& Rashid, N.H. (2016). Entrepreneurship impact on economic growth in emerging countries. The Business and Management Review, 7(2), 31-39. 